\title{
Assigning Energetic Archetypes to a Digital Cadastre and Estimating Building Heat Demand. An Example from Hamburg, Germany
}

\author{
Ivan DOCHEV ${ }^{1 *}$, Hannes SELLER ${ }^{2}$, Irene PETERS ${ }^{3}$ \\ ${ }^{1-3}$ HafenCity University Hamburg, Hamburg, 20457, Germany
}

\begin{abstract}
In view of the relatively large energy consumption of national building stocks, many cities and municipalities start to prepare energetic building stock models to monitor energy efficiency and plan policies at city or regional scales. In many cases, data on individual buildings is not available. A usual approach to this is the "archetype" approach - classifying the building stock into energetic types (archetypes). This classification is usually based on non-energetic properties available in digital cadastres (construction type, year of construction etc.) and can be a large source of error. We present our research into the difficulties and pitfalls associated with such an approach using the city of Hamburg as an example. In the end, we compare the modelled estimates with consumption data at three different levels to evaluate model performance.
\end{abstract}

Keywords - energetic archetypes; UBEMs (Urban building energy models); urban heat demand.

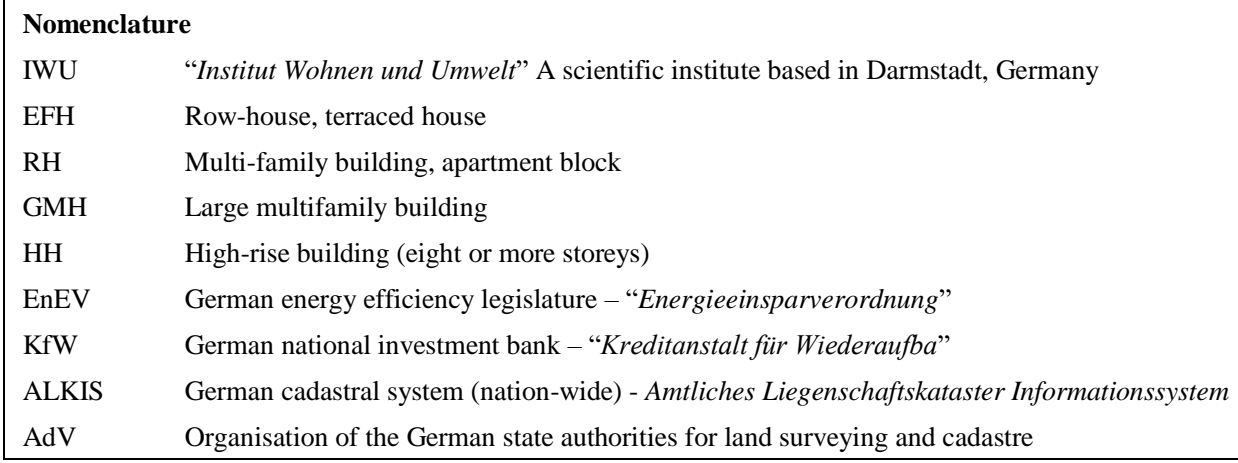

\section{INTRODUCTION}

In the context of the European climate goals and the German Energy Transition, the demand for heat energy is beginning to receive much attention. Thus, the understanding of the building stock, being one of the main consumers of energy in general and of heat energy in particular, becomes a key issue for many European cities - smart cities need smart energy planning. This, on the other hand, requires information on building heat demand, not only in the totals

\footnotetext{
* Corresponding author.

E-mail address: ivan.dochev@hcu-hamburg.de 
but also spatially distributed in order to support local planning and policy (see example [1], $[2])$.

There are two general approaches to urban energy modelling - top-down and bottom-up. The top-down approach usually involves distributing a total energy amount to spatial units buildings, census tracts etc. based on floor areas, population or similar. These models are easier to set up, potentially more realistic, but less flexible and therefore less suitable for policy analysis than the bottom-up models. The latter usually involve a digital cadastre with non-energetic information about buildings (size, location, age etc.) which is used for deriving energetic properties based on "archetypes" - representative buildings, with known energetic characteristics. Setting up the building model then comes down to matching or "assigning" the archetypes to the buildings in the cadastre so that energetic properties for each building can be estimated. The next step is energy simulation.

\section{OвJECTIVE}

The purpose of this paper is to present our work and experience in using the "archetype" approach to urban heat demand modelling at the building scale in Hamburg, Germany. We aim at presenting a comprehensive and detailed description of the steps we took, the difficulties we encountered and the solutions we came up with, in the hope that it would be useful for others in the field.

\section{Literature OVERVIEW}

Keirstead, Jennings et al. [3] presented a review of the broader field of urban energy modelling, identifying six key areas of practice: technology design, building design, urban climate, systems design, policy analysis and land-use and transportation modelling. Reinhart and Cerezo [4] give a good overview of the more concrete area of urban building energy modelling with applications in building and policy design, comparing approaches from multiple cities and countries (US, UK, Italy, Spain, France, Germany, Japan, Netherlands and others). Their conclusions are that the field is emerging and going in the direction of energy flow modelling on neighbourhood level. The challenges are the definition and description of archetypes, the unavailability of measured data for validation and the deterministic modelling of user behaviour. Further, Cerezo et al. compared four approaches [5] to archetype modelling as a case study for Kuwait City - deterministic with a single archetype, deterministic with four archetypes, deterministic with a probabilistic handling of user behaviour and a Bayesian approach to building characteristics combined with the same probabilistic handling of the user behaviour. They report best results with the Bayesian approach. Kristensen et al. [6] also make use of Bayesian statistics for a hierarchical calibration of archetypes and dynamic energy modelling of an aggregate of 100 buildings. They report estimation errors between model prediction and observed consumption of $2.9 \%$ (normalised mean bias error) and $7.8 \%$ (coefficient of variation of the root mean square error). Monteiro et al. [7] presented a method for archetype characterization and analysed the impact of the number of archetypes on model performance. Their results vary between $55.2 \mathrm{GWh}$ and $64 \mathrm{GWh}$ for a specific area, noting that the percent difference is relatively small, but $8.8 \mathrm{GWh}$ in absolute terms make a difference for energy supply. A slightly different problem - data standardisation and integration in urban energy modelling is discussed by Chen et al. [8]. They analyse four US cities and report that all four local datasets are suitable for energy modelling, however they require standardized formats and workflow. The literature overview shows that various scientific groups are working on different ends of this emerging field, tackling issues like 
number of archetypes, archetype definitions and user behaviour. A work closely connected to our paper is by Nouvel el al. [9], who integrate 3D models in UBEMs, while using the same typology as we use in this paper. Nouvel el al. concentrate, however, on the 3D data and the simulation, while we aim at exploring the intermediate, but key step in the general process the assigning of the archetypes to the buildings.

\section{Methods And Procedures}

In this chapter we first describe the two sets of archetypes that we use (one for residential and one for non-residential buildings). Then we describe the features and properties of the digital cadastre that we use and lastly the challenges of assigning the archetypes to the individual buildings in the cadastre. We also discuss the pitfalls when dealing with building uses, mixed-use buildings and floor areas. A python script for automating the whole process is available on GitHub*.

\subsection{Data and Archetypes}

\subsubsection{The IWU Typology}

The IWU residential building typology was prepared by the Institut Wohnen und Umwelt Darmstadt (IWU) [10] as part of the European TABULA Project and deals with residential buildings and demand for space heating and hot water only. It is based on a sample study of the German residential building stock. It makes use of three building characteristics which are used to classify a building into a specific energetic "archetype": the construction epoch (e.g. epoch 'B': 1860 ... 1918), construction type (e.g. "single-family house" or "apartment building") and a renovation level. An overview of the archetypes of the IWU Typology is presented in Table 1 below (see Nomenclature for the meaning of the abbreviations). Note that there are missing positions, for example, there is no archetype for RH_A. We address this issue in section 4.2.3.

TABLE 1. OVERVIEW OF ALL IWU TYPES

\begin{tabular}{ll|lllll}
\hline Epoch & $\begin{array}{l}\text { Construction } \\
\text { epoch code }\end{array}$ & & & \multicolumn{2}{c}{ Construction types } \\
\hline$\ldots 1859$ & A & EFH & - & MFH & - & - \\
$1860 \ldots 1918$ & B & EFH & RH & MFH & GMH & \\
$1919 \ldots 1948$ & C & EFH & RH & MFH & GMH & - \\
$1949 \ldots 1957$ & D & EFH & RH & MFH & GMH & \\
$1958 \ldots 1968$ & E & EFH & RH & MFH & GMH & HH \\
$1969 \ldots 1978$ & F & EFH & RH & MFH & GMH & HH \\
$1979 \ldots 1983$ & G & EFH & RH & MFH & & \\
$1984 \ldots 1994$ & H & EFH & RH & MFH & & \\
$1995 \ldots 2001$ & I & EFH & RH & MFH & & \\
$2002 \ldots 2009$ & J & EFH & RH & MFH & - & \\
$2010 \ldots 2015$ & K & EFH & RH & MFH & \\
$2016 \ldots$ & L & EFH & RH & MFH & \\
\hline
\end{tabular}

\footnotetext{
${ }^{*}$ https://github.com/ivandochev/assigning-energetic-types-to-buildings
} 
The typology includes all of the listed types in three renovation levels: '0' or "baseline", ' 1 ' corresponding to the energy efficiency standard of the German energy efficiency legislature (Energieeinsparverordnung, EnEV 2014) and '2' which is the "Passive House" standard developed at the TU Darmstadt in the 1990s. "Passive" in this sense means the building does not require active heating due to very high levels of insulation and can be heated via the ventilation system. Note that "baseline" in this context differs from "original state". "Baseline" means the energetic state in which a certain archetype is currently mostly to be found. It does not assume only original building characteristics. For example, the "baseline" state of a single-family house built prior to 1859 includes windows with a two-pane insulated glazing and a U-value of $2.8 \mathrm{~W} /\left(\mathrm{m}^{2} \mathrm{~K}\right)$ [10], which is not with what the building was originally built with. Since the original windows were no more to be found, according to the sample survey of IWU, the "baseline" state does not contain original windows, but the most common ones currently, for the respective archetype. For newer buildings (epochs $\mathrm{K}$ and L) the "renovation level" translates to the energy efficiency standard of construction with ' 0 ' being the current minimum standard for new buildings according to the EnEV. The next two levels (' 1 ' and '2') correspond to the "KfW-Effizienzhaus 70" and "KfW-Effizienzhaus 40" standards. These were defined by the KfW (Kreditanstalt für Wiederaufbau), which is the German national investment bank. The numbers 70 and 40 mean $70 \%$, respectively, $40 \%$ less primary energy demand (per sq. meter) compared to the current energy efficiency standard.

IWU described the energetic characteristics (U-values, A/V ratios etc.) and calculated specific heat demand per annum $\left(\mathrm{kWh} / \mathrm{m}^{2} /\right.$ year) by using a "reference building" - a building that mostly represents a given archetype. Although IWU calculated the specific heat demand for each archetype they also provide a "consumption" correction - an empirical function to reduce the discrepancy between "demand" (calculated with a standard, usually static, heat balancing method) and "consumption" (measured empirically). Thus, the values for the archetypes are comparable with consumption data. Still, since the demand is calculated (albeit with a consumption correction), IWU could provide values at different points in the heating system - for "useful heat" (emitted by radiators, water taps), for "demand at generation" (Wärmeerzeugung, amount needed as output of heat generator) and for "final energy" (amount needed as input to heat generator). All specific heat demands have the heated residential floor area (Wohnfläche) as the reference area.

We chose this typology because: a) it is well-documented, b) it is well established in Germany, c) it is part of an international EU project (TABULA/EPISCOPE [11]), where similar typologies are prepared for more than 20 European countries, and d) includes a consumption correction to allow comparison with measured data.

\subsubsection{VDI $3807-2$}

The German standard VDI 3807-2 (Characteristic consumption values for buildings) [12] is a publication by the Association of German Engineers (Verein Deutscher Ingenieure). It includes a classification of non-residential buildings into building uses and specific consumption values for each. We view the building uses as 'archetypes' in the context of this paper. The main goal of the publication is to allow the comparison between non-residential buildings of the same archetype and thus provide building owners, or energy auditors with an idea how energy efficient a building is.

For each of the archetypes, the VDI includes a sample of buildings with measured consumption of water, electricity and heat (including domestic hot water). The heat consumption is for space heating and hot water only, process heat is not included, although 
some VDI archetypes can be classified as "industrial" buildings. The VDI publication includes mean, mode and median values as well as a frequency distribution. The specific values (per sq. meters) use the mode value of the frequency distribution. The publication also includes a "reference value" (we call it "target value", to avoid confusion with "reference area") - the arithmetic mean of the lower quartile. In a sense, the mode value is where most buildings currently are and the target value is the value that buildings should "strive for". All specific values have the heated gross floor area as the reference area. We use the mode value of the VDI as an equivalent to the IWU "baseline" renovation level and the "target value" as an equivalent to "renovation level 1". For non-residential buildings we do not have an equivalent of renovation level 2. All values from the VDI are, per definition, final energy, since they are based on measured consumption. The IWU consumption correction allows the use of the IWU archetypes alongside the VDI archetypes, since both in the end reflect consumption.

We chose this typology for the non-residential archetypes, because it is well documented, consumption-based and derived from a sample with available frequency distribution. The latter means the suspected heterogeneity of archetypes is more quantifiable and transparent. Modelling non-residential buildings is a more difficult task than modelling residential ones exactly because these buildings vary greatly. The cadastres in Germany are not rich enough in detail to allow the assigning of more finely defined archetypes. Therefore, we decided not to search for more detailed non-residential archetypes, but to rely on average consumptions for heterogenic archetypes, so that at least at an aggregated level we can have more realistic results.

\subsubsection{ALKIS}

The Hamburg digital cadastre (ALKIS - Amtliches Liegenschaftskataster Informationssystem) is the target for the assigning of the building archetypes. The ALKIS is a standardized cadastral system used throughout Germany. We make use of the building objects (AX_Gebäude) in the cadastre, stored as polygon geometry and attributes. There are approximately 300000 building objects in Hamburg. The attributes relevant for our purposes are: building use, construction year, construction type, number of storeys, roof type and footprint area. The ALKIS of Hamburg is freely available in CityGML format from the "transparency portal" of Hamburg [13].

\subsection{Assigning the Archetypes}

This chapter deals with the interpretation of the attributes and the logic used for assigning both sets of archetypes (IWU and VDI) to each building, based on its attributes.

\subsubsection{Building Uses}

In order to assign an archetype to a building polygon, the first thing to decide is whether the building is residential or non-residential, since we have two sets of archetypes. This immediately poses a problem with mixed-use buildings. In the ALKIS, each mixed-use building has its own use-name. For example, "Residential building with Commerce and Services" (Wohngebäude mit Handel und Dienstleistungen) is a distinct building use. Rather than defining "custom-made" archetypes for mixed-use buildings, we view each building polygon as having two zones - residential and non-residential. Purely residential buildings have zero non-residential area, while purely non-residential buildings have zero residential area. Mixed-use buildings have both. Respectively, mixed-use buildings have both an IWU 
and a VDI archetype assigned, while buildings of a single use, only one archetype. We consider only a mix of residential and another type of building use. Other mix of uses is simplified by assigning only a VDI archetype.

To tackle the mixed-use buildings, we had to decide what non-residential use to assign, based on the building's name and definition in the cadastre. Additionally, we had to define the ratio between the residential and non-residential area (the two zones). Table 2 shows how we tackled this. The table starts with four single-use building uses, which is an excerpt from the total of 232 building uses (see github repository for full table). Out of these 232 uses, 13 are mixed-use buildings and are presented below the four examples of single-use buildings. We operationalize the assigning of types by first assigning an "overall use class", which can be "residential", "commerce and industry", "public", "mixed-residential" and "irrelevant". Since the VDI differentiates only between building uses, the assigning of a VDI archetype to the ALKIS is simply mapping the appropriate VDI use-name to the respective ALKIS use-name, as shown in Table 2. For residential buildings, we further differentiate between the archetypes of IWU. This means that a polygon with "residential" overall use class is taken to a second step where we assign the appropriate IWU archetype. "Irrelevant" buildings are buildings that we assume have none or negligible amount of heat demand. The "public" overall use class does not affect the assigning of archetypes. We added it for quicker querying and further analysis after the types are assigned and the building model is prepared. The assumed share of residential area is based on our experience and knowledge of the Hamburg building stock.

TABle 2. AsSUMPtions ABOUt MiXED-USE BuILDINGS (EXCERPT)

\begin{tabular}{|c|c|c|c|c|}
\hline ALKIS Name & $\begin{array}{l}\text { ALKIS } \\
\text { Code }\end{array}$ & $\begin{array}{l}\text { Overall } \\
\text { building use* }\end{array}$ & VDI Name & $\begin{array}{l}\text { Assumed share of } \\
\text { residential area }\end{array}$ \\
\hline Wohngebäude & 1000 & residential & - & $100 \%$ \\
\hline $\begin{array}{l}\text { Gebäude für Wirtschaft } \\
\text { oder Gewerbe }\end{array}$ & 2000 & $\begin{array}{l}\text { commerce and } \\
\text { industry }\end{array}$ & Werkstätten & $0 \%$ \\
\hline Verwaltungsgebäude & 3000 & public & Verwaltungsgebäude allg & $0 \%$ \\
\hline Gartenhaus & 1313 & irrelevant & - & - \\
\hline$\ldots$ & $\ldots$ & $\ldots$ & $\ldots$ & $\ldots$ \\
\hline $\begin{array}{l}\text { Wohngebäude mit Handel } \\
\text { und Dienstleistungen }\end{array}$ & 1120 & $\begin{array}{l}\text { mixed } \\
\text { residential }\end{array}$ & Verkaufsstätten & $\begin{array}{l}100 \% \text { minus the } \\
\text { area of the ground } \\
\text { floor }\end{array}$ \\
\hline $\begin{array}{l}\text { Wohn- und } \\
\text { Geschäftsgebäude }\end{array}$ & 1123 & $\begin{array}{l}\text { mixed } \\
\text { residential }\end{array}$ & Verkaufsstätten & $\begin{array}{l}100 \% \text { minus the } \\
\text { area of the ground } \\
\text { floor }\end{array}$ \\
\hline $\begin{array}{l}\text { Wohngebäude mit } \\
\text { Gemeinbedarf }\end{array}$ & 1110 & $\begin{array}{l}\text { mixed } \\
\text { residential }\end{array}$ & Gemeindehäuser & $50 \%$ \\
\hline $\begin{array}{l}\text { Wohn- und } \\
\text { Verwaltungsgebäude }\end{array}$ & 1121 & $\begin{array}{l}\text { mixed } \\
\text { residential }\end{array}$ & Verwaltungsgebäude allg & $50 \%$ \\
\hline Wohn- und Bürogebäude & 1122 & $\begin{array}{l}\text { mixed } \\
\text { residential }\end{array}$ & Verwaltungsgebäude allg & $50 \%$ \\
\hline $\begin{array}{l}\text { Wohngebäude mit } \\
\text { Gewerbe und Industrie }\end{array}$ & 1130 & $\begin{array}{l}\text { mixed } \\
\text { residential }\end{array}$ & Betriebsgebäude/-höfe & $50 \%$ \\
\hline $\begin{array}{l}\text { Wohn- und } \\
\text { Betriebsgebäude }\end{array}$ & 1131 & $\begin{array}{l}\text { mixed } \\
\text { residential }\end{array}$ & Betriebsgebäude/-höfe & $50 \%$ \\
\hline $\begin{array}{l}\text { Land-und } \\
\text { forstwirtschaftliches } \\
\text { Wohngebäude }\end{array}$ & 1210 & $\begin{array}{l}\text { mixed } \\
\text { residential }\end{array}$ & Betriebsgebäude/-höfe & $50 \%$ \\
\hline
\end{tabular}




\begin{tabular}{|c|c|c|c|c|}
\hline $\begin{array}{l}\text { Land- und } \\
\text { forstwirtschaftliches } \\
\text { Wohn- und } \\
\text { Betriebsgebäude }\end{array}$ & 1220 & $\begin{array}{l}\text { mixed } \\
\text { residential }\end{array}$ & Betriebsgebäude/-höfe & $50 \%$ \\
\hline $\begin{array}{l}\text { Wohn- und } \\
\text { Wirtschaftsgebäude }\end{array}$ & 1222 & $\begin{array}{l}\text { mixed } \\
\text { residential }\end{array}$ & Betriebsgebäude/-höfe & $50 \%$ \\
\hline $\begin{array}{l}\text { Gemischt genutztes } \\
\text { Gebäude mit Wohnen }\end{array}$ & 1100 & $\begin{array}{l}\text { mixed } \\
\text { residential }\end{array}$ & Verwaltungsgebäude allg & $15 \%$ \\
\hline $\begin{array}{l}\text { Gebäude für Handel und } \\
\text { Dienstleistung mit } \\
\text { Wohnen }\end{array}$ & 2310 & $\begin{array}{l}\text { mixed } \\
\text { residential }\end{array}$ & Verkaufsstätten & $15 \%$ \\
\hline $\begin{array}{l}\text { Gebäude für Gewerbe und } \\
\text { Industrie mit Wohnen }\end{array}$ & 2320 & $\begin{array}{l}\text { mixed } \\
\text { residential }\end{array}$ & Betriebsgebäude/-höfe & $15 \%$ \\
\hline
\end{tabular}

It is clear that heterogeneity is highly likely to be present within a single ALKIS use code, but this is an innate problem of the archetype approach. An extreme example of such heterogeneity is the Gemischt genutztes Gebäude mit Wohnen (Code 1100, "mixed-use building with residential"). Some large shopping centres, like the Billstedt Zentrum, have this building use in the ALKIS, but also some much smaller 1-2 storey buildings that can be viewed as single-family houses. Since the name does not hint towards a specific share, we took some of the largest such buildings and looked at each to get an idea about the possible split. Based on this, we assumed a share of $15 \%$ residentially used area. This represents our best guess from a non-representative sample.

\subsubsection{Construction Epoch}

The construction epoch is used to differentiate between different residential archetypes. The logic behind using the epoch as a proxy for building characteristics lies in the assumption that buildings built within one epoch were similar, therefore allow classification into archetypes. For older epochs, the assumption mostly relies upon typical materials and construction. For newer epochs, after the oil crisis in the late 1970s, it lies in the energy efficiency legislature that saw energy efficiency standards being increasingly demanding. That is why newer epochs encompass fewer years - because legislation to increase energy efficiency changed (and changes) more rapidly in the last 10-15 years.

Although information on the construction year of buildings is part of the ALKIS, its quality varies throughout Germany. In the concrete case of Hamburg, the ALKIS provides data on the construction year of roughly $50 \%$ of the residential buildings. This $50 \%$ however covers approximately $80 \%$ of the floor area, since most multi-family buildings have this entry. Whether these construction years in the ALKIS are correct is out of the scope of this paper, but we are further researching this question. Since most of the floor area of residential buildings has construction year entries, we decided to tackle the buildings without construction year in a simplistic way. We define a generic IWU archetype for each IWU construction type as an average of the heat demand for all epochs. For example, the generic single-family house type we define as $\mathrm{EFH}_{-}$and its specific heat demand is equal to the arithmetic mean of all single family house types (EFH_A to EFH_I). Note that the average excludes epochs J, K, and L, spanning from 2002 to 2016 . We found out after personal talks with the local administration, that an obligation to note down the construction year was introduced after 1998, so it is unlikely that a building without a construction year in the ALKIS would have been built after this date. We take 2002 as the cut-off as a precaution. 


\subsubsection{Construction Type ('Bauweise')}

In order to assign the IWU archetypes, the construction type of each polygon has to be defined. The ALKIS includes an attribute "Bauweise", which can be translated as "construction type". However, the "Bauweise" is not the same as the IWU definition of construction type. When assigning their types to German Census data, IWU came up with the following allocation of types to data in the census [10].

TABLE 3. DEFINITIONS OF THE CONSTRUCTION TYPES OF THE IWU ARCHETYPES

\begin{tabular}{ll}
\hline Type & Description \\
\hline Einfamilienhaus (EFH) & Detached residential building with 1 or 2 dwellings \\
Reihenhaus (RH) & Semi-detached residential building or row house with 1 or 2 dwellings \\
Mehrfamilienhaus (MFH) & Residential building with between 3 and 12 dwellings \\
Großes Mehrfamilienhaus (GMH) & Residential building with more than 13 dwellings \\
\hline
\end{tabular}

IWU explicitly states that this logic is not to be followed strictly if other building data is available [10]. For example, the distinction between MFH and GMH is set at twelve dwelling units, only because this was the threshold in the census statistics. However, this approach cannot be taken for Hamburg since the ALKIS does not record number of dwellings per building. Therefore, we assigned the construction types of IWU based on the Bauweise and the number of storeys of a building polygon. An overview of the Bauweise and some explanations are presented in Table 4. Establishing the connection between the Bauweise and the IWU construction type requires some explanations. The definitions of the Bauweise types for the ALKIS in the ALKIS documentation give some insights. For example, the Bauweise "Gruppenhaus" is defined by the AdV (Organisation of the German state authorities for land surveying and cadastre - (Arbeitsgemeinschaft der Vermessungsverwaltungen der Länder der Bundesrepublik Deutschland) as: "Gruppenhaus" is one of more than two attached buildings of the same kind, with usually up to $2 \frac{1}{2}$ storeys, which are arranged in such a way that no single axis exists between them - ("Gruppenhaus" ist eines von mehr als 2 gleichartigen, aneinandergebauten Wohnhäusern mit in der Regel bis zu 21/2 Geschossen, die so gegeneinander verschoben sind, dass keine gemeinsame Achse gegeben ist.) [14].

However, there is a discrepancy between this definition and the reality of most buildings with this "Bauweise" in Hamburg. Although these Gruppenhaus buildings should usually have up to $2 \frac{1}{2}$ storeys, in 11000 cases in Hamburg, the buildings have three or more storeys (as noted in the cadastre). In most cases these buildings can be viewed as rows of multi-family buildings, so the "no single axis exists between them" is also not applicable.

We traced this inconsistency between the official definitions of the Bauweise and the Hamburg ALKIS to when Hamburg adopted the ALKIS (around 2010). Before this, Hamburg had a digital cadastre that used a building use classification that was a mixture between "use" and "Bauweise". For example, single-family residential buildings had the use name "detached single-family house" (Einfamilienhaus-Einzelhaus). Therefore, a building use included three pieces of information: a) the building is residential, b) the building is detached and c) the building is a single-family house. When Hamburg opted for the ALKIS, these former use names were translated into the building uses of the ALKIS and the Bauweise of the ALKIS, as two separate attributes. As part of this transformation however, discrepancies occurred between the official definition of the different Bauweise and the actual characteristics of the buildings, which were given these Bauweise types. Because of this, we view the Bauweise as a translation of the older building use types and not as defined by the 
$\mathrm{AdV}$. We found the most probable correspondence between the older cadastre and the ALKIS by spatially joining the ALKIS with a version of the older cadastre.

We use Table 2 as a starting point. However, we need other building information to decide between the three multi-family types (MFH, GMH and $\mathrm{HH}$ ), between EFH and RH for the Bauweise "Doppelhaushälfte" and between EFH and MFH for "Freistehendes Einzelgebäude". For this, we use the number of storeys. Since the purpose of assigning archetypes is to assign the one archetype that is most similar to a given building polygon, we looked at the number of storeys of the reference buildings of IWU (Table 5). Additionally we looked at the "typical number of storeys" as given by IWU in the description of their typology [10].

\section{TABLE 4. ThE “BAUWEISE” ATTRIBUTE IN THE HAMBURG ALKIS}

\begin{tabular}{|c|c|c|c|}
\hline $\begin{array}{l}\text { Bauweise } \\
\text { Code }\end{array}$ & Name & $\begin{array}{l}\text { Description and use code prior to } \\
\text { ALKIS }\end{array}$ & IWU construction type \\
\hline 1100 & $\begin{array}{l}\text { Freistehendes } \\
\text { Einzelgebäude }\end{array}$ & $\begin{array}{l}\text { Usually used for detached } \\
\text { single-family houses, this } \\
\text { corresponds to the } \\
\text { "Einfamilienhaus-Einzelhaus" in } \\
\text { the digital cadastre of Hamburg } \\
\text { before the ALKIS was adopted }\end{array}$ & $\begin{array}{l}\text { Can be regarded as EFH } \\
\text { (single-family house) in the } \\
\text { IWU typology. However, some } \\
\text { buildings have more than two } \\
\text { storeys. It is unlikely that a } \\
\text { building with three or four } \\
\text { storeys is a single-family } \\
\text { house. Therefore, it could be } \\
\text { closer to a MFH in some cases. }\end{array}$ \\
\hline 1200 & $\begin{array}{l}\text { Freistehender } \\
\text { Gebäudeblock }\end{array}$ & $\begin{array}{l}\text { Usually used for detached multi- } \\
\text { family houses, this corresponds to } \\
\text { the "Mehrfamilienhaus-- } \\
\text { Einzelhaus" }\end{array}$ & $\begin{array}{l}\text { Can be regarded as MFH, } \\
\text { GMH or HH (multi-family } \\
\text { building, large multi-family } \\
\text { building or high-rise). }\end{array}$ \\
\hline 1300 & Einzelgarage & & \\
\hline 1400 & Doppelgarage & Not relevant, we consider garages as & hon-heated. \\
\hline 1500 & Sammelgarage & & \\
\hline 2100 & Doppelhaushälfte & $\begin{array}{l}\text { Twin-buildings, usually used for } \\
\text { single-family houses; corresponds } \\
\text { to the "Einfamilienhaus- } \\
\text { Doppelhaus" }\end{array}$ & $\begin{array}{l}\text { Can be regarded as RH (row- } \\
\text { house) or EFH. }\end{array}$ \\
\hline 2200 & Reihenhaus & $\begin{array}{l}\text { Row-houses, usually single-family } \\
\text { houses; corresponds to } \\
\text { "Einfamilienhaus-Gruppenhaus" }\end{array}$ & Regarded as RH \\
\hline 2300 & Haus in Reihe & Not present in Hamburg ALKIS & $\begin{array}{l}\text { Can be regarded as MFH, } \\
\text { GMH or HH }\end{array}$ \\
\hline 2400 & Gruppenhaus & $\begin{array}{l}\text { Corresponds to } \\
\text { "Mehrfamilienhaus-- } \\
\text { Gruppenhaus" }\end{array}$ & Generally regarded as $\mathrm{MFH}$, \\
\hline 2500 & $\begin{array}{l}\text { Gebäudeblock in } \\
\text { geschlossener } \\
\text { Bauweise }\end{array}$ & $\begin{array}{l}\text { Corresponds to } \\
\text { "Mehrfamilienhaus-Wohnblock" }\end{array}$ & $\mathrm{GMH}$ or $\mathrm{HH}$ \\
\hline 4000 & Offene Halle & \multirow{3}{*}{\multicolumn{2}{|c|}{$\begin{array}{l}\text { Not relevant, considered as "Missing Bauweise" if building function } \\
\text { is residential. }\end{array}$}} \\
\hline 9999 & Sonstiges & & \\
\hline 0 & Missing value & & \\
\hline
\end{tabular}


Note that deciding between EFH, MFH and GMH could be done using the gross floor area, since, for example, a GMH is, by definition, a large MFH. This, however, quickly becomes problematic, since the borders between connected buildings are not systematic in the ALKIS. A building with three entrances is sometimes split into three polygon objects, sometimes not. Multiple row-houses are sometimes given as a single polygon object with the "Bauweise" "Reihenhaus". This will result in a gross floor area much larger than that of a row-house and could lead to assigning a MFH type. For such reasons we do not consider the gross floor area as a signal when assigning an IWU construction type.

TABle 5. OVERVIEW OF THE TyPiCAL Number OF FloOrs AbOVE GROUND OF THE CONSTRUCTION TYPES

\begin{tabular}{|c|c|c|c|c|c|c|c|c|c|c|c|}
\hline \multirow{3}{*}{ Years } & \multirow{3}{*}{ Epoch } & \multicolumn{10}{|c|}{ IWU Construction Types - Number of storeys above ground } \\
\hline & & \multicolumn{2}{|l|}{ EFH } & \multicolumn{2}{|c|}{ RH } & \multicolumn{2}{|c|}{ MFH } & \multicolumn{2}{|l|}{ GMH } & \multicolumn{2}{|l|}{ HH } \\
\hline & & typical & Ref. & typical & Ref. & typical & Ref. & typical & Ref. & typical & Ref. \\
\hline ... 1859 & A & $1-2$ & 2 & - & & $2-4$ & 4 & - & & - & \\
\hline $\begin{array}{l}1860 \ldots \\
1918\end{array}$ & B & $1-2$ & 2 & 2 & 2 & $3-4$ & 4 & $4-5$ & 5 & - & \\
\hline $\begin{array}{l}1919 \ldots \\
1948\end{array}$ & $\mathrm{C}$ & $1-2$ & 2 & 2 & 2 & $3-4$ & 3 & $5-6$ & 5 & - & \\
\hline $\begin{array}{l}1949 \ldots \\
1957\end{array}$ & D & $1-2$ & 1 & 2 & 2 & $3-4$ & 3 & $5-8$ & 5 & - & \\
\hline $\begin{array}{l}1958 \ldots \\
1968\end{array}$ & E & $1-2$ & 1 & 2 & 2 & $3-5$ & 4 & $5-8$ & 8 & $>8$ & 15 \\
\hline $\begin{array}{l}1969 \ldots \\
1978\end{array}$ & F & $1-2$ & 1 & 2 & 2 & $3-5$ & 4 & $5-8$ & 8 & $>8$ & 15 \\
\hline $\begin{array}{l}1979 \ldots \\
1983\end{array}$ & G & $1-2$ & 2 & 2 & 2 & $3-5$ & 3 & - & & - & \\
\hline $\begin{array}{l}1984 \ldots \\
1994\end{array}$ & $\mathrm{H}$ & $1-2$ & 1 & $2-3$ & 2 & $3-5$ & 3 & - & & - & \\
\hline $\begin{array}{l}1995 \ldots \\
2001\end{array}$ & I & $1-2$ & 1 & $2-3$ & 2 & $3-5$ & 4 & - & & - & \\
\hline $\begin{array}{l}2002 \ldots \\
2009\end{array}$ & $\mathrm{~J}$ & $1-2$ & 2 & $2-3$ & 2 & $3-5$ & 3 & - & & - & \\
\hline $\begin{array}{l}2010 \ldots \\
2015\end{array}$ & $\mathrm{~K}$ & - & 2 & - & & - & & - & & - & \\
\hline $2016 \ldots$ & $\mathrm{L}$ & - & 2 & $-/ 2$ & & -15 & & - & & - & \\
\hline
\end{tabular}

In most cases, a distinction between MFH, GMH and HH can be made based on the typical number of storeys. In the cases where the typical number of storeys in one epoch overlaps for two types, we take the construction type with number of storeys closest to the reference building. For example, in epoch E (1958 ... 1968), a MFH typically has four or five storeys while a GMH - five to eight storeys. If a building is a multi-family building with five storeys, it could be categorized as both MFH and GMH. However, looking at the reference buildings, for these two epochs - MFH_E and MFH_F have four storeys, while GMH_E and GMH_F have eight storeys. We consider that the characteristics of a five-storey building probably are more similar to those of a four-storey one than to an eight-storey one (both in the same epoch). We assign MFH. This constitutes a "best guess". 
Some buildings with Bauweise "Freistehendes Einzelgebäude" have more than two storeys in the ALKIS, which is unlikely for a single-family house. Since all reference buildings of the IWU typology for type EFH are up to two storeys, while MFH starts at three in many cases we assign EFH only if it has up to two storeys.

The Doppelhaushälfte, or "twin buildings" are closest to an "end-house" from a row of row-houses. Since there is no such IWU construction type, we assign a row-house type and assume that the characteristics are closer to a row house than to a detached single-family house. IWU also classifies these buildings as row-houses [10].

Lastly, Tables 1 and 5, indicate an additional problem - there are some combinations of IWU construction type and epoch that are undefined. For example, there is no archetype RH_A, we assign EFH_A, since they are both single-family houses, although one is detached, the other is not. For the other construction types - GMH, HH, also not present in epoch A, we assign MFH. Having a building with more than eight storeys (HH) before 1859 (epoch A) is highly unlikely, therefore we view this as unproblematic.

We approach the other missing combinations in a similar way - epoch-wise. This means we fill out the gaps with different construction types of the same epoch, rather than with the "appropriate" construction type from another epoch. The majority of relevant missing combinations are GMH and $\mathrm{HH}$ for epochs after F. Although typically the high-rise buildings in Hamburg were built in the 60s and the 70s, there are some built after that and it is unreasonable to assume that they would be only a few. For all of these combinations we assign MFH for the appropriate epoch and not GMH or HH from another epoch. Our choice lies in the energy efficiency legislation after the 1970s. It is stated in $\$ 2$ of the first German thermal insulation ordinance (WärmeschutzV) from 1977 [15] that the (then) new residential buildings (and some non-residential ones) were required to adhere to standards regarding the U-values of outer walls and windows. The minimal U-values were, however, dependent upon the Area-to-Volume ratio (" $A / V$ ") of a building - higher minimal U-values were set for lower $A / V$ s. Generally, larger buildings have a lower $A / V$ ratio making them more energy-efficient. Considering that the U-value standard for larger buildings started being proportional to the $A / V$, means that the overall energy-efficiency of buildings started to even out between smaller and larger buildings after 1977, at least when geometry and transmissivity is viewed. Larger buildings had higher U-values, smaller buildings lower U-values. For this reason, we fill the missing combinations of construction type and epoch "horizontally" - retaining the epoch, and not "vertically" retaining the construction type. We are not aware if this was the reasoning for the lack of these combinations in the first place. There are some building polygons in the ALKIS without a "Bauweise" entry. For these we use only the number of storeys. An overview of all archetype-assignment rules for residential buildings is given in Table 6 .

Table 6. OVERVIEW OF ASSIGNING RULES

\begin{tabular}{|c|c|c|c|c|c|}
\hline Epoch & $\begin{array}{l}\text { Epoch } \\
\text { Code }\end{array}$ & Bauweise & $\begin{array}{l}\text { Bauweise } \\
\text { Code }\end{array}$ & $\begin{array}{l}\text { Number of } \\
\text { storeys }\end{array}$ & Assigned type \\
\hline \multirow{6}{*}{$\begin{array}{l}\text { before } \\
1859\end{array}$} & \multirow{6}{*}{ A } & Freistehendes Einzelgebäude & 1100 & \multirow{3}{*}{$\begin{array}{l}\leq 2 \text {, else regarded } \\
\text { as missing } \\
\text { bauweise }\end{array}$} & \multirow{3}{*}{ EFH_A } \\
\hline & & Doppelhaushälfte & 2100 & & \\
\hline & & Reihenhaus & 2200 & & \\
\hline & & Freistehender Gebäudeblock & 1100 & \multirow{3}{*}{ any } & \multirow{3}{*}{ MFH_A } \\
\hline & & Haus in Reihe * & 2300 & & \\
\hline & & Gruppenhaus & 2400 & & \\
\hline
\end{tabular}




\begin{tabular}{|c|c|c|c|c|c|}
\hline & & $\begin{array}{l}\text { Gebäudeblock in geschlossener } \\
\text { Bauweise }\end{array}$ & 2500 & & \\
\hline & & Miscina Raupoise & & 1,2 & EFH_A \\
\hline & & Mnssing Bauwetse & - & $>2$ & MFH_A \\
\hline \multirow{10}{*}{$\begin{array}{l}1860- \\
1957\end{array}$} & \multirow{10}{*}{$\begin{array}{l}\mathrm{B}, \mathrm{C}, \\
\mathrm{D}\end{array}$} & Freistehendes Einzelgebäude & 1100 & \multirow{3}{*}{$\begin{array}{l}\leq 2 \text {, else regarded } \\
\text { as missing } \\
\text { Bauweise }\end{array}$} & EFH_B/C/D \\
\hline & & Doppelhaushälfte & 2100 & & \multirow{2}{*}{ RH_B/C/D } \\
\hline & & Reihenhaus & 2200 & & \\
\hline & & Freistehender Gebäudeblock & 1100 & \multirow{4}{*}{$\begin{array}{l}\leq 4 \\
\geq 5\end{array}$} & \multirow{4}{*}{$\begin{array}{l}\text { MFH_B/C/D } \\
\text { GMH_B/C/D }\end{array}$} \\
\hline & & Haus in Reihe & 2300 & & \\
\hline & & Gruppenhaus & 2400 & & \\
\hline & & $\begin{array}{l}\text { Gebäudeblock in geschlossener } \\
\text { Bauweise }\end{array}$ & 2500 & & \\
\hline & & \multirow{3}{*}{ Missing Bauweise } & \multirow{3}{*}{-} & 1,2 & EFH_B/C/D \\
\hline & & & & 3,4 & MFH_B/C/D \\
\hline & & & & $\geq 5$ & GMH_B/C/D \\
\hline \multirow{11}{*}{$\begin{array}{l}1958- \\
1978\end{array}$} & \multirow{11}{*}{$\mathrm{E}, \mathrm{F}$} & Freistehendes Einzelgebäude & 1100 & \multirow{3}{*}{$\begin{array}{l}\leq 2 \text {, else regarded } \\
\text { as missing } \\
\text { Bauweise }\end{array}$} & EFH_E/F \\
\hline & & Doppelhaushälfte & 2100 & & \multirow{2}{*}{ RH_E/F } \\
\hline & & Reihenhaus & 2200 & & \\
\hline & & Freistehender Gebäudeblock & 1100 & \multirow{4}{*}{$\begin{array}{l}\leq 5 \\
6,7,8 \\
>8\end{array}$} & \multirow{4}{*}{$\begin{array}{l}\text { MFH_E/F } \\
\text { GMH_E/F } \\
\text { HH_E/F }\end{array}$} \\
\hline & & Haus in Reihe & 2300 & & \\
\hline & & Gruppenhaus & 2400 & & \\
\hline & & $\begin{array}{l}\text { Gebäudeblock in geschlossener } \\
\text { Bauweise }\end{array}$ & 2500 & & \\
\hline & & \multirow{4}{*}{ Missing Bauweise } & \multirow{4}{*}{-} & 1,2 & EFH_E/F \\
\hline & & & & $3,4,5$ & MFH_E/F \\
\hline & & & & $6,7,8$ & GMH_E/F \\
\hline & & & & $>8$ & HH_E/F \\
\hline \multirow{9}{*}{$\begin{array}{l}1979- \\
2016\end{array}$} & \multirow{9}{*}{$\begin{array}{l}\mathrm{G}, \mathrm{H}, \mathrm{I} \\
\mathrm{J}, \mathrm{K}, \mathrm{L}\end{array}$} & Freistehendes Einzelgebäude & 1100 & \multirow{3}{*}{$\begin{array}{l}\leq 2 \text {, else regarded } \\
\text { as missing } \\
\text { Bauweise }\end{array}$} & EFH_G/H/I/J/K/L \\
\hline & & Doppelhaushälfte & 2100 & & \multirow{2}{*}{ RH_G/H/I/J/K/L } \\
\hline & & Reihenhaus & 2200 & & \\
\hline & & Freistehender Gebäudeblock & 1100 & \multirow{4}{*}{ any } & \multirow{4}{*}{ MFH_G/H/I/J/K/L } \\
\hline & & Haus in Reihe & 2300 & & \\
\hline & & Gruppenhaus & 2400 & & \\
\hline & & $\begin{array}{l}\text { Gebäudeblock in geschlossener } \\
\text { Bauweise }\end{array}$ & 2500 & & \\
\hline & & \multirow{2}{*}{ Missing Bauweise } & \multirow{2}{*}{-} & 1,2 & EFH_G/H/I/J/K/L \\
\hline & & & & $>2$ & MFH_G/H/I/J/K/L \\
\hline
\end{tabular}

\subsubsection{Reference Areas}

After we assign the IWU and VDI archetypes to each building polygon, we have to estimate the reference area to calculate the total heat demand. The residential archetypes of IWU have the residential floor area as reference area. The VDI archetypes use the heated gross floor area ("beheizbare Bruttogrundfläche") [12]. Note that there is another German term that can also be translated as heated gross floor area - Nutzfläche EnEV according to the German 
Energy Saving Ordinance EnEV. According to it, the Nutzfläche EnEV is calculated using the entire heated volume (measured from the outside) of the envelope of a building and then multiplying with 0.32 (Or in a more complicated way for heights - outside the 2.5-3.0 metre range. We, however, neglect this for the purpose of this paper). Although "Nutzfläche" means "useable" area, per definition, it is very similar to the "beheizbare Bruttogrundfläche" for the majority of buildings. The difference is in that one is volume-based (Nutzfläche EnEV), the other is area-based. This can lead to large discrepancies with buildings with atriums or similar non-standard volumes. Since we use a two-dimensional cadastre, we can only estimate both the volume and the floor area based on footprint and number of storeys. Therefore, for our purposes, we cannot differentiate between Nutzfläche EnEV and beheizbare Bruttogrundfläche and take them as equivalent and equal to the heated gross floor area.

For both sets of archetypes, we first estimate the heated gross floor area by multiplying the number of storeys with the footprint areas. For residential buildings, we also consider heated attics, since they are not included in the number of storeys. To estimate the area of heated attics, we list the roof forms, which could have a heated attic - Table 7. Flat roofs and more uncommon types (domes) are not considered.

\section{TABLE 7. OVERVIEW OF ROOF TyPES THAT COULD BE “HEATED”}

\begin{tabular}{lll}
\hline English Term & German Term & Roof Type Code \\
\hline Gable/Saddle Roof & Satteldach & 3100 \\
Hip Roof & Walmdach & 3200 \\
Half-hip Roof & Krüppelwalmdach & 3300 \\
Mansard Roof & Mansardendach & 3400 \\
\hline
\end{tabular}

Then, from these four roof types we define different rules to estimate if they are heated. The Mansard Roof we assume to be always heated, because Mansard roofs were generally invented in order to provide living space beneath the roof shell. Similarly, the Half-hip Roof we also always consider heated. For the other two types - Gable/Saddle Roof and Hip Roof a reference to the IWU Typology is made [10]. We consider a building polygon with Gable/Saddle Roof as having a heated attic, if the IWU archetype of the building polygon is listed in the typology description as having a heated attic ("EFH_A", "EFH_B", "EFH_C", “EFH_D”, "EFH_E”, "RH_B”, "RH_C”, “RH_D”, "RH_E”, "MFH_A") [10].

All residential buildings for which the attic is thusly considered heated receive an additional area of $75 \%$ of the footprint area. This is $25 \%$ less than an additional floor to compensate for the reduced volume beneath the roof shell and possible false assumption whether the attic is heated. Expressed as a formula this amounts to (1) for residential buildings with heated roofs and (2) for all others (including non-residential).

$$
\begin{gathered}
A=a(s+0.75), \\
A=a s,
\end{gathered}
$$

where:

A heated gross floor area, $\mathrm{m}^{2}$;

a footprint area, $\mathrm{m}^{2}$;

$s \quad$ number of storeys.

After we estimate the heated gross floor area, we apply the coefficients for share of residential area (Table 2) and tackle residential and non-residential buildings differently. 
Non-residential buildings use the heated gross floor area as reference area, therefore we do not calculate further. Residential buildings use the residential floor area as reference area and we use the coefficients in Table 8 to convert heated gross floor area to residential area. For mixed-use buildings we take the non-residential share of the area as it is, and apply the conversion coefficients only to the residential part of the area. The numbers in Table 8 are based on our analysis of a sample of residential buildings with energy certification, where both areas are noted.

TABLE 8. OVERVIEW OF COEFFICIENTS USED FOR CONVERTING HEATED GROSS FloOR AREA TO RESIDENTIAL AREA

\begin{tabular}{lll}
\hline $\begin{array}{l}\text { Construction type } \\
\text { (IWU Typology) }\end{array}$ & $\begin{array}{l}\text { Conversion } \\
\text { coefficient }\end{array}$ & Note \\
\hline EFH & 0.77 & $\begin{array}{l}\text { Equals the average ratio for all the reference buildings in the } I W U \\
\text { typology with this construction type (all } E F H \text { s and } R H \text { s respectively) }\end{array}$ \\
RH & 0.81 & $\begin{array}{l}\text { The average ratio is } 0.84 \text {. However } 4 \% \text { were removed since some } \\
\text { "purely" residential buildings according to the } A L K I S \text { actually have } \\
\text { nFH }\end{array}$ \\
$\begin{array}{ll}\text { non-residential uses within them which leads to an overestimation of the } \\
\text { total residential floor area. }\end{array}$ \\
HH
\end{tabular}

\subsubsection{D Data and "Building Parts"}

There are two issues with using the number of storeys and the footprint area for estimating gross floor area. Firstly, the storey height is relevant for heat demand, since the same gross floor area can have different total volumes based on how high each storey is. This is somewhat tackled by the archetype approach and the reference buildings behind it. We argue, that given that the specific heat demands assigned to the polygons come from a reference building, the floor heights would be implicitly in the archetype. IWU simulated the reference buildings with measured floor heights from construction plans, therefore the reference building has a "typical" floor height encoded in the specific heat demand of the archetype.

A bigger issue is the presence of buildings with multiple "bodies" with different number of storeys, all within the same building footprint. In this case, only the maximum number of storeys is usually found in the ALKIS for the given polygon. This leads to large overestimations of building volume. An example is presented in Fig. 1. Interestingly, official 3D data for Hamburg [16] even in the second level of detail (LoD2), which includes roof forms, also fails to tackle this problem.

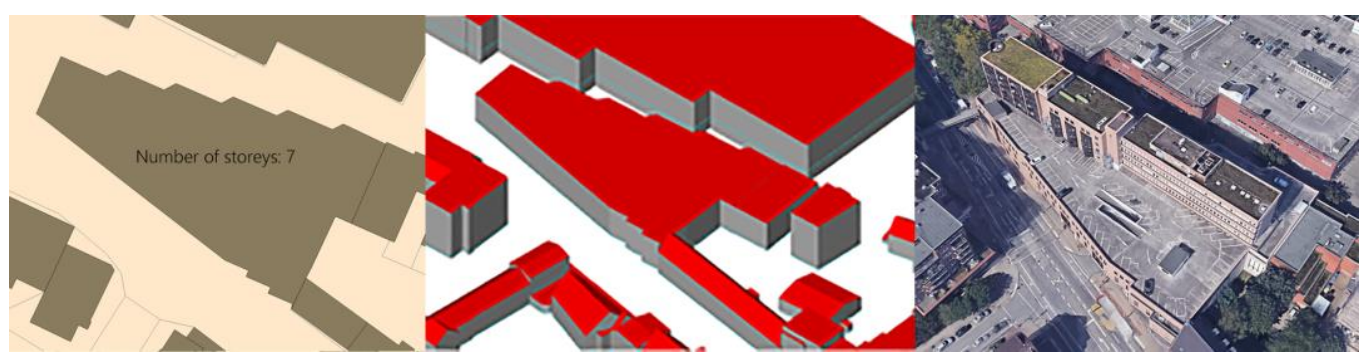

Fig. 1. False volume estimations. Left to right: ALKIS, 3D model (LoD2) and Google Earth. 
Using 3D data has the advantage of more precise volumes of simpler buildings, however simpler buildings are the ones where using number of storeys and footprint is most plausible. In a way, 3D fails where needed most - complex and extraordinary buildings. For this reason, we do not use 3D data for our model currently.

However, the 2D ALKIS actually provides for such situations, where additional cadastral objects "building parts" describe higher, lower or overarching building bodies within the same building (Fig. 2).
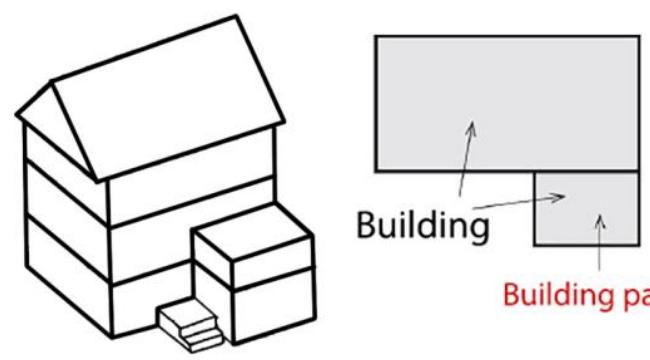

\section{Building part}

Fig. 2. Example of "building parts" in the ALKIS. Adapted from the official documentation of the ALKIS [17].

Building parts have a separate number of storeys. We use this to either increase (higher building part - "Hoehergeschossiger Gebaeudeteil (nicht Hochhaus)" or "Hochhausgebaeudeteil") or decrease (lower building part "Geringergeschossiger Gebaeudeteil") the heated gross floor area. In this way, we correct for the over- or underestimation of the gross floor area due to different heights within the same building footprint.

Note that, regrettably, "building parts" are not always consistently noted in the ALKIS of Hamburg and there are buildings with different number of storeys that are not properly described. The quality of this aspect of the ALKIS seems to be regional specific. We analysed the ALKIS buildings in the "Moabit" neighbourhood of Berlin, for example, and found it to be more complete with respect to building parts. The Berlin ALKIS is available from the Berlin geoportal [18].

\subsubsection{Renovation Levels}

The issue of a building's renovation level is one of the most difficult due to the lack of data. Although the building archetypes are based on the state a building is to be found "currently" (actually, the IWU sample is from 2010, the VDI most probably prior to that - 2007), there are probably many buildings with much higher energy efficiency. Using the ALKIS we cannot model this and expect the model to overestimate the heat demand.

\section{Results}

\subsection{Reference Area Plausibility}

As a major correlator to total heat demand, we first check the plausibility of our reference area estimations. For the residential floor area, this is possible using census data. We sum up all areas of the buildings according to "city quarters" (Stadtteil) which is an official administrative division. Hamburg is divided into approximately 100 such quarters. At this 
level of aggregation census data on total residential floor area is available from the Hamburg statistics office [19]. A correlation analysis of our estimation of the residential floor area and the census data (Fig. 3) produced a very good fit.

Residential floor area in Stadtteile [mill. sq. m.]

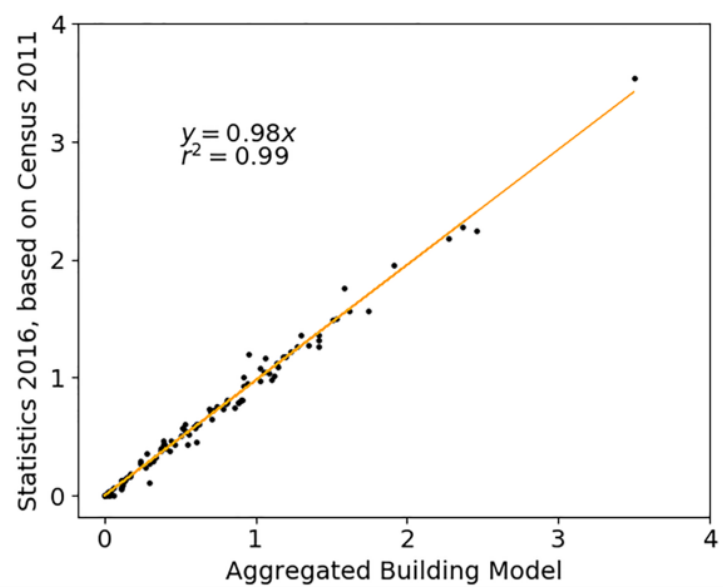

Fig. 3. Correlation between estimated residential floor area and official statistics at the "Stadtteil" level (an administrative division of Hamburg).

Validating the non-residential floor area at these scales is not possible, since there are no official statistics on this.

\subsection{Heat Demand Plausibility}

A good estimation of the residential floor area is necessary for the estimation of the total heat demand; however, the latter is of more importance for the purposes of this paper. We check heat demand plausibility at three different scales: city, neighbourhood and building.

\subsubsection{City-scale}

Since Hamburg is a city-state within the German Federation, state-level data is equivalent to city-level data. The Hamburg Statistics Office publishes state-level energy balances for different years [20]-[22]. We look at the years 2014-2016, the three most recent for which data is published. The statistics office derives this data from measurements from energy providers. Public bodies usually use this data for reference for policy analysis and $\mathrm{CO}_{2} \operatorname{target}$ tracking. However, the data differentiates and cross-tabulates between fuel-type and user-type, but not usage. This means the total amount of $\mathrm{kWh}$ used by households, commercial and business sector and industrial sector in Hamburg is present in the statistics. The fuel-type (gas, district heating, electricity, oil etc.) used for this energy is also present. The end usage (space heating, domestic hot water, cooking, appliances etc.) is not. Since we model only heat demand, we need to estimate how much each of the user groups uses for this purpose. For this we use a national split estimated and published by the Working Group on Energy Balances (Energy Balances Group) [23]. This is a German association including energy industry and research institutes. According to their publication from 2017, on average, households in Germany use $86 \%, 81.3 \%, 6.6 \%, 91.9 \%, 100 \%$ and $87.3 \%$ of their oil, gas, 
electricity, district heating, coal and renewable energy consumption respectively for space heating. Figures for domestic hot water are also available in the same publication. Using the local statistics for years 2014-2016, we first calculate the $\mathrm{kWh}$ used for space heating and hot water for each year using the above split (which is an average for Germany). We then correct the space heating for weather conditions using degree-days. In the end, we average the consumption for the three years.

We consider that our heat demand estimation for the residential gross floor area in Hamburg corresponds to the heat consumption of households in the statistics. Similarly, we consider our heat demand estimation for the non-residential gross floor area as comparable with the consumption of the user group "commerce, services, business" and "industry". Note that we model only space heating and domestic hot water. In addition, for this comparison we used "useful heat" for residential buildings. Comparing final energy would be more appropriate, however information on types of heating systems is not available for the whole city and therefore we could not model final energy. For non-residential buildings the specific heat demand of the archetypes is consumption-based - the mode of a sample distribution therefore, it averages over the losses of the different heating systems of the sample.

TABLE 9. COMPARISON OF TOTAL ESTIMATED HEAT DEMAND AND ENERGy STATISTICS

\begin{tabular}{|c|c|c|c|c|c|}
\hline Heat Demand of Hamburg, GWh & Source & Households & CBS* & Industry & Total \\
\hline Space Heating (weather corrected) & & 7297 & 6354 & 424 & 14074 \\
\hline Domestic Hot Water & Statistics Office & 1513 & 503 & 43 & 2059 \\
\hline Space Heating + DHW & & $\underline{8810}$ & \multicolumn{2}{|c|}{$\underline{7324}$} & $\underline{16134}$ \\
\hline Space Heating + DHW & Model & $\underline{9559}$ & \multicolumn{2}{|c|}{$\underline{9314}$} & $\underline{18873}$ \\
\hline
\end{tabular}

*Commercial, Business, Services

The results in Table 9 show that the model is overall plausible. As expected, the model overestimates the data in the statistics. Note that since the model does not account for recent renovations, but uses useful energy instead of final energy (for residential buildings) some averaging out effects are present. The non-residential heat demand is consumption-based and as expected is overestimated in the model. This can be due to the presence of recently renovated buildings, but also due to an overestimated reference area (we could not validate the reference area of non-residential buildings).

\subsubsection{Neighbourhood Scale}

As second plausibility check we use an energetic planning report, for a part of the Bergedorf neighbourhood in Hamburg [24]. The report gives $38.8 \mathrm{GWh}$ as measured heat consumption for the whole territory of the neighbourhood $\left(\sim 0,3 \mathrm{~km}^{2}\right.$, secondary urban centre with a mixture of residential and non-residential buildings). For the same territory, our model gives a value of $41.1 \mathrm{GWh}$. No distinction is made between residential and non-residential consumption in the report, so we cannot validate separately.

\subsubsection{Building Scale}

Lastly, we compare our estimation of heat demand for seven non-residential building complexes in Hamburg (Table 10) with energy audits obtained as part of the GEWISS Project [25]. Due to data protection reasons we name the complexes A to F. Each complex has 
between two and seven buildings. The uses vary between educational buildings, sport facilities, small-scale production facilities and large manufacturing plants.

TABLE 10. COMPARISON BETWEEN MEASURED CONSUMPTIONS AND MODEL ESTIMATES AT BUILDING/COMPLEX LEVEL

\begin{tabular}{lllllll}
\hline & \multicolumn{2}{l}{ Measured from energy audit } & \multicolumn{2}{l}{ Estimated by model } \\
\hline $\begin{array}{l}\text { Building } \\
\text { Complex }\end{array}$ & $\begin{array}{l}\text { Heat } \\
\text { Consumption, } \\
\text { MWh }\end{array}$ & $\begin{array}{l}\text { Useable } \\
\text { Area, } \mathbf{m}^{2}\end{array}$ & $\begin{array}{l}\text { Specific } \\
\text { Consumption, } \\
\mathbf{k W h} / \mathbf{m}^{2}\end{array}$ & $\begin{array}{l}\text { Heat } \\
\text { Demand, } \\
\mathbf{M W h}\end{array}$ & $\begin{array}{l}\text { Heated } \\
\text { floor Area, } \\
\mathbf{m}^{\mathbf{2}}\end{array}$ & $\begin{array}{l}\text { Specific } \\
\text { Demand, } \\
\mathbf{k W h} / \mathbf{m}^{\mathbf{2}}\end{array}$ \\
\hline A & 2097 & 15691 & 133.7 & 1788 & 16059 & 111.4 \\
B & 1160 & 5850 & 198.3 & 1140 & 8124 & 140.3 \\
C & 224 & 1018 & 219.6 & 60 & 600 & 100.3 \\
D & 532 & 3300 & 161.1 & 318 & 3225 & 98.7 \\
E & 388 & 4650 & 83.5 & 614 & 6556 & 93.6 \\
F & 12767 & 85331 & 149.6 & 25127 & 339558 & 74.0 \\
\hline $\begin{array}{l}\text { Total } \\
\text { (excluding F) }\end{array}$ & 4401 & 30509 & 144.2 & 3920 & 34564 & 113.4 \\
\hline
\end{tabular}

This comparison shows that there are discrepancies at the building level, in terms of not only specific heat demand but also floor areas. In some cases, errors in area and specific heat demand cancel each other out and the total demand is close to the actual consumption (A, B). In other cases, the specific heat demand is close, but the area estimation leads to large discrepancies (E). Complex $\mathrm{F}$ has a hugely overestimated floor area, however the useable area noted in the energy audit has in places large floor heights - more than 20 meters. Our heated floor area always assumes a standard floor height, it is, therefore, not comparable. Summing up all demands and areas for complexes $\mathrm{A}$ to $\mathrm{E}$ shows that on average the estimation is plausible although far from precise. We exclude complex F, since it is two orders of magnitude larger than the rest and it has to be viewed separately or it will overshadow all other examples if aggregated with them.

Overall, the model performs plausibly at the city and neighbourhood scales with discrepancies in range of $20 \%$. This is similar to other such models in the literature [4].

\section{Conclusion AND OUTLOOK}

As shown, although at first glance seemingly straightforward, the task of assigning an energetic archetype to a digital cadastre can quickly become complex and ridden with assumptions. In many cases, we based our assumptions on experience and the peculiarities of German digital cadastres. However, the problems we encountered are, most probably, not specific only to Germany, since they arise from an unavoidable, key step in the general archetype approach - matching the archetypes to the objects in a cadastre.

Although performing plausibly, our model is far from perfect. The main problem with residential buildings is the lack of a systematic, exhaustive register or accounting of which buildings have undergone renovations already. This is true for non-residential buildings as well, however their heterogeneity also goes against the archetype approach in general. 
Nevertheless, due to averaging out effects at the aggregated levels our model performed reasonably.

\section{ACKNOWLEDGEMENTS}

This paper was prepared as part of the development of the Hamburg Heat Demand Cadastre (Wärmekataster) and the GEWISS Project in Hamburg [25], financed by the Federal Ministry for Economic Affairs and Energy and the Hamburg Ministry of Environment and Energy. We would like to thank Ms. Lubow Hesse, Mr. Arne Werner and Mr. Roland Schwörer from the Hamburg Ministry of Environment and Energy for the fruitful cooperation.

\section{REFERENCES}

[1] Pakere I., Lauka D., Blumberga D. Estimation of Carbon Emission Reduction from Upgrading the DH Network to the 4th Generation. Multivariate Linear Regression Model. Environmental and Climate Technologies 2019:23(2):6473. https://doi.org/10.2478/rtuect-2019-0055

[2] Jekabsone A., Kamenders A., Rosa M., Kaselofsky J., Schule R. Assessment of the Implementation of Sustainable Energy Action Plans at Local Level. Case Study of Latvia. Environmental and Climate Technologies 2019:23(2):3646. https://doi.org/10.2478/rtuect-2019-0053

[3] Keirstead J., Jennings M., Sivakumar A. A review of urban energy system models: Approaches, challenges and opportunities. Renewable and Sustainable Energy Reviews 2012:16(6):3847-3866. https://doi.org/10.1016/j.rser.2012.02.047

[4] Reinhart C. F., Cerezo C. D. Urban building energy modeling - A review of a nascent field, Building and Environment 2016:97:196-202. https://doi.org/10.1016/j.buildenv.2015.12.001.

[5] Cerezo C., Sokol J., AlKhaled S., Reinhart C., Al-Mumin A., Hajiah A. Comparison of four building archetype characterization methods in urban building energy modeling (UBEM): A residential case study in Kuwait City. Energy and Buildings 2017:154:321-334. https://doi.org/10.1016/j.enbuild.2017.08.029

[6] Kristensen M. H., Hedegaard R. E., Petersen S. Hierarchical calibration of archetypes for urban building energy modelling. Energy and Buildings 2018:175:219-234. https://doi.org/10.1016/j.enbuild.2018.07.030

[7] Monteiro C. S., Pina A., Cerezo C., Reinhart C., Ferrao P. The Use of Multi-detail Building Archetypes in Urban Energy Modelling. Energy Procedia 2017:111:817-825. https://doi.org/10.1016/j.egypro.2017.03.244

[8] Chen Y., Hong T., Luo X., Hooper B. Development of city buildings dataset for urban building energy modelling. Energy and Buildings 2019:183:252-265. https://doi.org/10.1016/j.enbuild.2018.11.008

[9] Nouvel R., Brassel K.-H., Bruse M., Duminil E., Coors V., Eicker U., Robinson D. SimStadt, a new workflow-driven urban energy simulation platform for CityGML models. Presented at CISBAT, International Conference "Future Buildings and Districts - Sustainability from Nano to Urban Scale", Lausanne, Switzerland, September 9-11, 2015.

[10] Loga T., Stein B., Diefenbach N., Born R. Deutsche Wohngebäudetypologie [German residential building typology]: Beispielhafte Maßnahmen zur Verbesserung der Energieeffizienz von typischen Wohngebäuden, 2015. http://www.building-typology.eu/downloads/public/docs/brochure/DE_TABULA_TypologyBrochure_IWU.pdf.

[11] Stein B., Loga T., Diefenbach N. (Eds.), Monitor progress towards climate targets in European housing stocks: Main results of the EPISCOPE Projekt final project report, Institut Wohnen und Umwelt GmbH, Darmstadt/Germany, 2016.

[12] The Association of German Engineers. Characteristic consumption values for buildings: Characteristic heating-energy, electrical-energy and water consumption values. [Online]. [Accessed 16.05.2018]. Available: http://www.vdi.eu/nc/guidelines/vdi_3807_blatt_2-

verbrauchskennwerte_fuer_gebaeude_verbrauchskennwerte_fuer_heizenergie_strom_und_wasser

[13] Landesbetrieb Geoinformation und Vermessung, ALKIS - ausgewählte Daten Hamburg [ALKIS data excerpt for Hamburg]. gml, 2018. [Online]. [Accessed 30.01.2019]. Available: http://datenhamburg.de/geographie_geologie_geobasisdaten/ALKIS_Liegenschaftskarte/ALKIS_Liegenschaftskarte_ausgewa ehlteDaten_HH_2018-10-06.zip

[14] Arbeitsgemeinschaft der Vermessungsverwaltungen der Länder der Bundesrepublik Deutschland, Dokumentation zur Modellierung der Geoinformationen des amtlichen Vermessungswesens (GeoInfoDok 7.1) [Documentation on the Modeling of Geoinformation of Official Surveying and Mapping]: ATKIS-Objektartenkatalog Basis-DLM, 2018. [Online]. $\quad$ [Accessed 21.01 .2020$]. \quad$ Available: http://www.advonline.de/icc/extdeu/nav/a63/binarywriterservlet?imgUid=9201016e-7efa-8461-e336-

b6951fa2e0c9\&uBasVariant=11111111-1111-1111-1111-111111111111 [accessed 21 January 2020].

[15] Verodnung über einen energiesparenden Wärmeschutz bei Gebäuden (Wärmeschutzverordnung) [Building thermal insulation ordinance]: WäremeschutzV, in: Bundesgesetzblatt, pp. 1554-1564. 
[16] Landesbetrieb Geoinformation und Vermessung, 3D-Stadtmodell LoD2-DE Hamburg. xml, 2017. [Online]. [Accessed 30.02.2019]. Available: http://datenhamburg.de/geographie_geologie_geobasisdaten/3d_stadtmodell_lod2/LoD2-DE_HH_2017-12-31.zip

[17] Arbeitsgemeinschaft der Vermessungsverwaltungen der Länder der Bundesrepublik Deutschland, Dokumentation zur Modellierung der Geoinformationen des amtlichen Vermessungswesens (GeoInfoDok) [Documentation on the Modeling of Geoinformation of Official Surveying and Mapping]: Erläuterungen zu ALKIS, 2006. [Online]. [Accessed 30.01.2019]. Available: http://www.adv-online.de/GeoInfoDok/GeoInfoDok-6.0/

[18] Senatsverwaltung für Stadtentwicklung und Wohnen, ALKIS Berlin (Amtliches Liegenschaftskatasterinformationssystem), 2015.

[19] Statistics Office for Hamburg and Schleswig-Holstein, Stadtteil Profile 2015, 2015. [Online]. [Accessed 16.05.2018]. Available: https://www.statistik nord.de/fileadmin/Dokumente/Datenbanken_und_Karten/Stadtteilprofile/Stadtteilprofile-Berichtsjahre-20072015.xlsx

[20] Statistics Office for Hamburg and Schleswig-Holstein, Energiebilanz und CO2-Bilanzen für Hamburg 2014 [Energy and CO2 balance for Hamburg 2014], 2016. [Online]. [Accessed 17.07.2018]. Available: https://www.statistiknord.de/fileadmin/Dokumente/Sonderver\%C3\%B6ffentlichungen/Energie-_und_CO2-

Bilanz_Hamburg/EB_CO2_HH_2014.pdf

[21] Statistics Office for Hamburg and Schleswig-Holstein, Energiebilanz und CO2-Bilanzen für Hamburg 2015 [Energy balance and CO2 balance for Hamburg 2015], 2017. [Online]. [Accessed 17.07.2018]. Available: https://www.statistik-nord.de/fileadmin/Dokumente/Sonderver\%C3\%B6ffentlichungen/Energie-_und_CO2Bilanz_Hamburg/EB_CO2_HH_2015.pdf

[22] Statistics Office for Hamburg and Schleswig-Holstein, Energiebilanz und CO2-Bilanzen für Hamburg 2016 [Energy balance and CO2 balance for Hamburg 2016], 2018. [Online]. [Accessed 17.07.2018]. Available: https://www.statistik-nord.de/fileadmin/Dokumente/Sonderver\%C3\%B6ffentlichungen/Energie-_und_CO2Bilanz_Hamburg/EB_CO2_HH_2016.pdf

[23] Arbeitsgemeinschaft Energiebilanzen e.V., Anwendungsbilanzen für die Endenergiesektoren in Deutschland in den Jahren 2013 bis 2016 [Final energy consumption by sector and type of use in Germany in the period 2013 2016], 2017. [Online]. [Accessed 17.07.2018]. Available: energiebilanzen.de/index.php?article_id=29\&fileName=ageb__zusammenfassender_bericht_fu__r_die_endenergiesektoren_2013_-_2016.pdf

[24] H. Diemann, M. Wulf, J. Bärschneider, J. Schülecke, C. von Lindenfels, M. Bonacker, P.C. Kowalsky, Energetische Stadtsanierung Bergedorf-Süd [Energetic urban renovation Bergedorf-South], Hamburg, 2013.

[25] GEWISS Project, GEWISS Geographisches Wärmeinformations- und Simulationssystem [Geographical Heat Information and Simulation System], 2018. [Online]. [Accessed 17.07.2018]. Available: http://gewiss.hawhamburg.de/
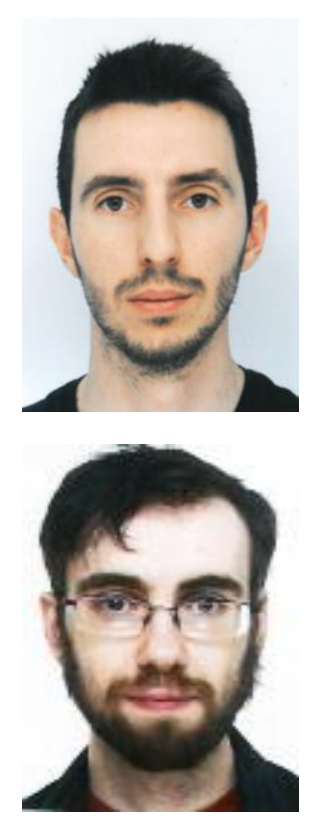

Ivan Dochev has a M.Sc. in urban planning from HafenCity University Hamburg and is currently a PhD student with the topic "Energy policy analysis with a building stock model based on spatial interpolation and microsimulation". He is currently part of the GEWISS Project Hamburg, financed by German Federal Ministry of Economic Affairs and Energy and Hamburg Ministry of Environment and Energy. His interests and expertise lie in building simulation, GIS and energy efficiency.

E-mail: ivan.dochev@hcu-hamburg.de

ORCID iD: https://orcid.org/0000-0002-0299-3558

Hannes Seller has a M.Sc. in Resource Efficiency in Architecture and Planning (REAP) from HafenCity University Hamburg and is currently a PhD student with the topic "Typologies of Urban Form for Urban Sustainability Planning". He is currently part of the GEWISS Project Hamburg, financed by the German Federal Ministry of Economic Affairs and Energy and the Hamburg Ministry of Environment and Energy. His interests and expertise lie in data visualization, GIS and energy efficiency.

E-mail: hannes.seller@hcu-hamburg.de 
Irene Peters studied economics and philosophy in Germany and the U.S. and holds a Ph.D. in economics from Clark University, MA (1994), with a focus on econometrics and modelling. She spent her work life at Tellus Institute for Resource and Environmental Strategies in Boston, U.S. (1985-1997), EAWAG (Swiss Federal Institute of Aquatic Science and Technology) (1997-2002), and as professor for Infrastructure Planning at TUHH (Hamburg University of Technology) (since 2003) and HCU (HafenCity University Hamburg) (since 2006). She teaches in Urban Planning and Resource Efficiency in Architecture and Planning, an interdisciplinary international M.Sc. programme. Her research interests are technical urban services planning and urban modelling. Her work in advisory committees includes (to name a few) "System Integration for Novel Sanitation Systems" of the German Association for Urban Water, "Climate Protection and Energy" of the International Building Exhibition Hamburg, Institute for Housing and Environment, Darmstadt.

E-mail: irene.peters@hcu-hamburg.de 